\title{
Influence of accessibility and distance in the consumption of disposable equipment in a hemodialysis unit
}

\author{
Antonio Torres-Quintana ${ }^{1}$, M Teresa Icart-Isern² ${ }^{2}$, Cristina Esquinas-López ${ }^{2}$ \\ From Health Services Research: Evidence-based practice \\ London, UK. 1-3 July 2014
}

\section{Background}

The location of the disposable material in a hemodialysis unit is essential to ensure the effectiveness of the circuits and to provide quality in nursing care.

The law of the minimum effort may explain how the accessibility and distance of dressing trolleys can influence the consumption of some health care supplies $[1,2]$. It is necessary for health managers to look for effective strategies that optimize the use of wound care material without reducing the quality of care $[1,3]$.

The objective was to determine whether the distance that nurses have to walk to access the trolley with the wound care material (gauzes, dressings and 10cc physiological serum), influence on the amount consumed in a hemodialysis unit at the Fundació Puigvert.

The research hypothesis is: consumption of those materials will decrease $5 \%$ as the distance to access the trolleys increases from 5 to 7 and from 7 to 9 meters.

\section{Materials and methods}

Thirty nurses (one trolley each one) under two shifts participated in a quasi-experimental design. For two months, trolleys were placed 5 meters away from the patient bed, another two months they were placed 7 meters and in the last two months the distance was 9 meters.

\section{Results}

Significant differences were observed comparing the consumption of physiological saline solution, gauzes and dressings when trolleys were located at 7 meters versus the 5 meters (being lower consumption, $\mathrm{p}<0.001$ ) and when they were located from 7 to 9 meters (consumption being lower, $\mathrm{p}<0.001)$. There was an inverse linear relationship between the consumption of gauze and dressings and experience of nurses for any distance $(R R=$ 1.26-0.112 duration; $\mathrm{p}=0.03$ ).

\section{Conclusions}

Correlation between consumption of material and age and experience was found inverse for all distances. A lower consumption of material by older and more experienced nurses was found. The location of material leads to a reduction in costs without any consequence in quality of care for patients in a hemodialysis unit.

\section{Authors' details}

${ }^{1}$ Unitat Hemodialisis. Fundació Puigvert, Barcelona, Spain. ${ }^{2}$ School of Nursing, University of Barcelona, Barcelona 08907, Spain.

Published: 7 July 2014

References

1. Zipf GK: Human behavior and the principle of least effort. Oxford, England: Addison-Wesley Press; 1949.

2. Miller RH, Umberger BR, Hamill J, Caldwell GE: Evaluation of the minimum energy hypothesis and other potential optimality criteria for human running. Proc Biol Sci 2011, 279:1498-505.

3. Hernàndez de $\operatorname{Cos} P$, Moral-Benito E: Eficiencia y regulación en el gasto sanitario en los países de la OCDE. Documentos ocasionales-Banco de España 2011, 7:5-36.

doi:10.1186/1472-6963-14-S2-P60

Cite this article as: Torres-Quintana et al.: Influence of accessibility and distance in the consumption of disposable equipment in a hemodialysis unit. BMC Health Services Research 2014 14(Suppl 2):P60.

${ }^{2}$ School of Nursing, University of Barcelona, Barcelona 08907, Spain

Full list of author information is available at the end of the article 